\title{
Public germplasm development at a crossroads: Biotechnology and intellectual property
}

\author{
Brian D. Wright
}

This year, U.S. growers planted 45 million acres of genetically engineered crops, primarily corn, soybeans, cotton and potatoes (Pollan 1998). These transgenic "smart crops" can produce their own insecticides, or withstand broad-spectrum herbicides such as Roundup or Liberty. Some say these developments signal the coming of age of the most profound technological revolution since the advent of computer technology.

But while transgenic crops promise new options for California farmers, they raise questions as well. For instance, a series of laws, legal judgments and Patent Office decisions during the last two decades have transformed property rights and incentives in the seed industry. Today genetic materials ranging from DNA sequences to whole plants, as well as essential biotechnology tools and techniques, are being patented by private and public research entities. At the same time, a series of mergers and acquisitions in the agrochemical and seed industries have led to increasing dominance by a small number of transnational corporations in these fields. Such industrywide changes signal a profound shift in the ownership of life forms and the recombinant DNA tools needed to manipulate them. How will the existing options for assigning "ownership" change the way in which germplasm development will occur? How will those changes affect farmers?
"The greatest service which can be rendered to any country is to add a useful plant to its culture."

\section{Thomas Jefferson}

$\Gamma$ buti he commercialization and distri-

bution of transgenic seeds has increased dramatically since 1996 . For instance, U.S. acreage planted to Roundup Ready® (glyphosate tolerant) soybeans went from 1 million to 9 million acres from 1996 to 1997, and Monsanto plans for the conversion of $100 \%$ of U.S. soybean acreage to the Roundup Ready® trait by 2000. Millions of acres of corn, cotton and potatoes have also been planted to transgenic varieties (Lappé, Bailey 1998).

Consumers are understandably cautious regarding transgenic technologies. But some of these technologies offer farmers benign substitutes for hazardous pesticides and herbicides, and they may provide consumers with an expanded food choices at lower prices. In response to the lure of profits from the new biogenetics, and the threat they pose to traditional agricultural chemical manufacturers, the agricultural crop protection and seed industries are rapidly becoming consolidated by transnational corporations (Wright 1998). Such corporations have had the capital necessary to finance long-term commercial development and field testing of transgenic technologies and crops. A small number of companies have, by merger and acquisition over the last 10 years, come to increasingly dominate the "life industries" (covering products ranging from seeds and agrochemicals to food, pharmaceuticals and veterinary medicines). In a striking analogy to the computer software industry, small biotechnology start-up companies tend to be integrated into this worldwide oligopoly once the promise of their technological innovations is proven.

These changes present problems both for growers of major crops such as corn, wheat and soybeans who will find they have an increasingly limited number of suppliers to choose from and for growers of minor specialty crops who may find that transgenic research that applies to them is never developed and commercialized because the potential market is too small to attract the attention of the private sector.

\section{Who owns germplasm?}

Historically, the germplasm (seeds and other breeding materials) of major agricultural crops was virtually held in common by all growers. After 1930 some plant varieties were protected by plant patents, but the protection applied only to clonally propagated varieties such as fruit trees or tubers.

Seeds purchased in the market could be freely used for further breeding by individual growers, university breeders, and seed companies. (For more on the history of relevant United States legislation, see Fowler 1994.) Even if stronger protection had been given to seed producers against unauthorized use for new varieties, enforcement would have been hampered by the difficulty of identifying proprietary germplasm as the parent of a new commercial variety. Only hybrid seeds that did not breed true were protected against this type of misappropriation.

In the last 20 years, it has become possible to patent life forms ranging from DNA sequences to whole plants, and including essential tools and techniques of genetic engineering. Breakthroughs in recombinant DNA tech- 
niques have buttressed these new property rights with technologies for enforcement. These have important consequences for California farmers and all farmers worldwide. For instance, what would happen if a rice variety, developed in California with public support, were modified by a company through genetic engineering to be herbicide tolerant? Does the new herbicide tolerant variety belong solely to the company? Do the original developers of the variety have rights over the germplasm? Do they derive any financial gain? To answer these questions we must direct our attention to how germplasm and genetic engineering tools are being protected as intellectual property.

\section{Who owns life forms?}

Farmers often view themselves as the rightful beneficiaries of genetic progress because generations of farmers have played a role in developing many cultivated crop varieties. Long before formal agricultural experiments were conducted, major crops were developing slowly in the farmers' fields, subject to selection pressure in local environments as well as to farmers' own selections. Successful cultivated varieties, or "cultivars," spread from farmer to farmer, or traveled with farmers as they migrated to new lands. Encounters with new soils, climates, insects and diseases engendered a great diversity of geography-specific cultivars, each dependent on human intervention but often not traceable to a single individual or location. Wild varieties, a major source for many other crops, also became diversified as they spread across different growth environments.

New genetic resources have long been viewed as a major source of national advantage (Juma 1989). Such genetic diversity has now become, in the eyes of many, the world's most valuable raw material, an essential component of a living organism's ability to adapt. But the beneficiaries of the biotechnological revolution will not necessarily include all those who have played a role in maintaining biodiversity. Ownership and legal control over biological resources (from
DNA sequences to entire plants) and the tools and processes of biotechnology is now being rapidly "privatized" by public and private innovators in the United States and elsewhere. The nature of these new private property rights, and how they are enforced, will determine the amount of resources invested in innovation, how effectively they are used and how benefits will be shared.

Before the 1980s, intellectual property rights were at best a weak source of incentive for plant breeding. Intellectual property claims of others placed no significant constraints on breeders' activities. The seeds they used, and their methods of breeding, came with no restrictions for breeding purposes, assuming the seeds had not been acquired in violation of trade secrecy protection.

Limits on duplication and sale of plants sold to farmers began in 1930 with the Plant Patent Act, which gave protection for the life of the patent to clonally propagated plants. The Plant Variety Protection Act of 1970 introduced the Plant Variety Protection Certificate (PVPC), which placed some restrictions on sale for replanting and covered many sexually reproduced plants. But use of plants for further breeding was unrestricted, provided the progeny were distinct from the parents. For example a new soybean cultivar, distinguished from its protected parent only by flower color, could be commercialized without restriction by a seed-industry competitor.

Until the recent revolution in biotechnology, stronger property rights in breeding materials would have been of only modest practical significance. Proof of parentage of a new, distinct progeny bred from a protected parent was too difficult to establish. Thus both legal and technical constraints inhibited the effective assertion of property rights by innovators in breeding materials. Breeders perceived little incentive to invest in improving germplasm that could be used gratis by competitors to produce new varieties that reproduced the improved traits.

The past few decades have witnessed a dramatic strengthening in legal protection of breeding materials and processes and their enforcement. Changes in patent law have allowed 


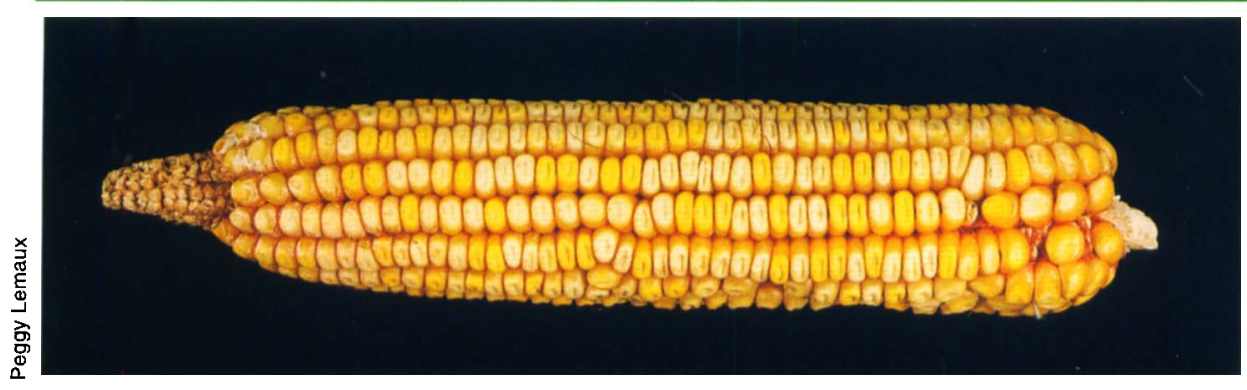

As biotech companies consolidate by merger and acquisition, growers of major crops including corn will find they have an increasingly limited number of suppliers to choose from.

corporations or individuals to obtain utility patents, the strongest form of patent protection, on life forms. In the early 1970s, General Electric brought a powerful test case on the patentability of a living organism (an oil-eating bacterium). The Supreme Court (Diamond v. Chakrabarty, 447 US 303, 1980) ruled in GE's favor and although the bacterium itself was not commercialized, the court decision ushered in a new era for utility patenting of life forms. In 1985, the ex parte Hibberd ruling confirmed that seeds, plants and tissue culture could be patented.

Today, companies seek the broadest possible patents on genes, seeds, clonally propagated plants, and highly sought-after biotechnology "tools" (such as vectors and promoters) and processes. Many corporations are applying for broad patents on genes, for medical and other purposes as well as agricultural uses. The U.S. Patent and Trademark Office received 4,000 patent requests for nucleic acid sequences in 1991 - and 500,000 in 1996 (Enriquez 1998).

As commonly occurs in the initial years of patenting in a novel technology area, the validity and scope of rights conferred in the Patent Office decision have remained uncertain. One among several notable examples is the pair of patents granted Agracetus (now owned by Monsanto) Covering all cotton created in the United States through any technique of genetic engineering. The "freedom to operate" of other cotton breeders in any area of biotechnology has remained under a cloud for years after the first application was filed in 1991 as the patents were granted, challenged, rejected and appealed (Powledge 1995; Robinson 1998).

Passage of the Bayh-Dole Amendment in 1980 gave researchers the right to patent federally funded research in nondefense areas. This allowed the profitable privatization of biotechnology to begin in the academic world, specifically with the nonexclusive licensing of their Nobel prize-winning recombinant DNA technology by UCSF's Herb Boyer and Stanford University's Stanley Cohen. Since then, the output of public researchers has been increasingly privatized, in the sense that others can use it only with the consent of the relevant property rights owner. The nature of the property rights depends upon the means of protection used.

\section{Means of IPR protection}

The recent strengthening of incengreatly expanded private investments in breeding of several major crops, and a rapid flow of promising new traits for crop protection or value-enhancing output modifications. But at the same time, the germplasm, tools and processes of modern breeding are no longer freely available, changing the effects of the intellectual property protection system. Short of outright acquisition, access must be obtained by one of several means, including:

1. Patent License: Patent licenses may be obtained on an exclusive or nonexclusive basis. Research licenses are often cheaper and easier to get than commercial licenses, but they allow use only in research - commercialization is precluded. Innovations achieved under a research license may tives for plant breeders has resulted in be blocked by the license holder, leaving the innovator in a weak bargaining position.

2. Material transfer agreement (MTA): An MTA is a contract for transfer and use of breeding inputs for deposit in a genebank, for research, or for commercial use. The transferred material must have some independent means of protection (e.g., patent or trade secrecy) to prevent its appropriation by third parties. In general, an MTA is a means of transferring material with "trade secret" protection, as embodied, for example, in various state laws in the United States. It may restrict the user's rights to improvement, resale or commercialization (Barton, Siebeck 1994).

MTAs are being used, for example, by the research centers of the Consultative Group on International Agricultural Research (CGIAR) to control the use of plant varieties held "in trust" on behalf of the countries of origin in their genebanks. If access to the materials is not otherwise available, this protection may be effective in preserving the provider's rights to the germplasm.

3. Bag-label contracts: Recently, Pioneer Hi-Bred International has sued some competitors alleging they selected self-pollinated seeds found in bags of a Pioneer hybrid corn seed and used them for breeding competitive hybrids. The basis of the suit appears to be the violation of restrictions included on the bag label (Miller 1998). If use of the seed for breeding is found to violate an implicit contract as described on a bag label, then bag label contracts are an additional means of protection of intellectual property.

4. Technology use agreement: An innovation in property rights enforcement, technology use agreements that control the right to plant a given seed type on a specific area of land have been implemented and enforced by producers of agronomic traits in the United States over the past few years. Their provisions can also include restrictions on the use of proprietary traits in the creation of new varieties.

5. Trade secret: In a celebrated case, Pioneer Hi-Bred International was 
awarded $\$ 46$ million in a 1994 Supreme Court decision for violation of Iowa trade secrecy law by Holden Foundation Seeds, Inc. The latter was alleged to have illegally acquired Pioneer inbred parent lines (used to breed commercial hybrid seed) for their own use. Modern methods of biotechnology (genetic fingerprinting) figured prominently in the evidence establishing the use of Pioneer germplasm in Holden's lines.

If a seed is to qualify for trade secrecy protection, it must be protected from acquisition by others. This may be feasible with "in-house" parent lines of commercial hybrids. But it is impossible to protect as a trade secret the information in the commercial seeds sold to farmers.

\section{IPR protection: the downside}

Many public researchers are coming to the realization that the availability of intellectual property protection for public research output is a mixed blessing when research has proceeded beyond the first generation of private technology (Koo 1998). Many of the innovations of their peers in their own or other public institutions are now available for use in further research only upon successful negotiation of the relevant property rights. The transaction costs involved in obtaining the necessary inputs (genes, promoters, markers, germplasm, transformation technology, etc.) can be very significant, and the validity and scope of the rights acquired might remain unresolved for years as patents are examined by the Patent Office and legal challenges make their way through the courts. Some companies have been spending many millions of dollars per year on lawsuits alone. Avoidance of such high transaction costs has been an important motivation for many mergers involving private firms in the agricultural biotechnology industry in recent years.
To produce genetically modified plants, such as the Endless Summer tomato, negotiations are often required between the companies that own biological resources (from DNA sequences to entire plants) and the owners of the tools and processes of biotechnology.

\section{Protection makes a difference}

Over the years the public sector in California, using mostly federal and state funds supplemented by support from some commodity groups, has been an important player in the development of new plant varieties. Classically bred varieties moved to the commercial field with no claims of legal protection. In today's agricultural arena, however, this policy is becoming problematic. The varying effectiveness of plant protection strategies practiced by public and private sector interests has dramatically influenced the balance of power between these interests in agricultural biotechnology.

Consider an example of how this situation could affect California rice growers. Assume public-sector breeders in California spent years developing a new rice variety, specifically suited for California. Support for this work included self-imposed producer assessments as well as state funds; the new seeds were distributed to farmers roughly at the cost of production.

Subsequently, a private agricultural biotechnology company acquired seeds of the variety and inserted genes for tolerance to their herbicides. The company would have invested substantial private resources developing the genetic engineering technologies needed to modify the rice variety, identifying appropriate gene(s) to confer the herbicide tolerance characteristic and discovering and registering the related herbicide.

The value of the herbicide tolerance would depend crucially on the productive potential of the elite germplasm into which the new gene was introduced. When the company offered the new, herbicide-tolerant variety back to the original developers of the cultivar or to the broader agricultural community, who would reap the financial benefits from the improved variety? The answer would depend upon whatever intellectual property rights protected the original cultivar, and the genes and processes used to engineer the plants.

If the original variety were unprotected or had a Plant Variety Protection Certificate (PVPC) available prior to 1994 , the original developer and its financial supporters would have no legal claim to share the profits from the new cultivar despite the fact that they successfully invested considerable resources in developing the original variety.

Additionally, if the seed company who bred the new herbicide-tolerant cultivar had no patent on the technology, and there was no protection available via hybridization, it would, after one season, find itself in competition with seeds grown by the first farmers to purchase and sow the seed, who could save their harvest for use or sale as rice seed. Most of the benefits then would accrue to farmers and consumers, rather than to the seed company.

Assume, on the other hand, the seed company had protected its technology with a patent. It would be legally free to charge what the market would bear for its product and keep all the profits, if the developer had not acquired intellectual property protection of the original cultivar.

Farmers in less-developed and developed countries, who over the centuries have helped develop landrace 


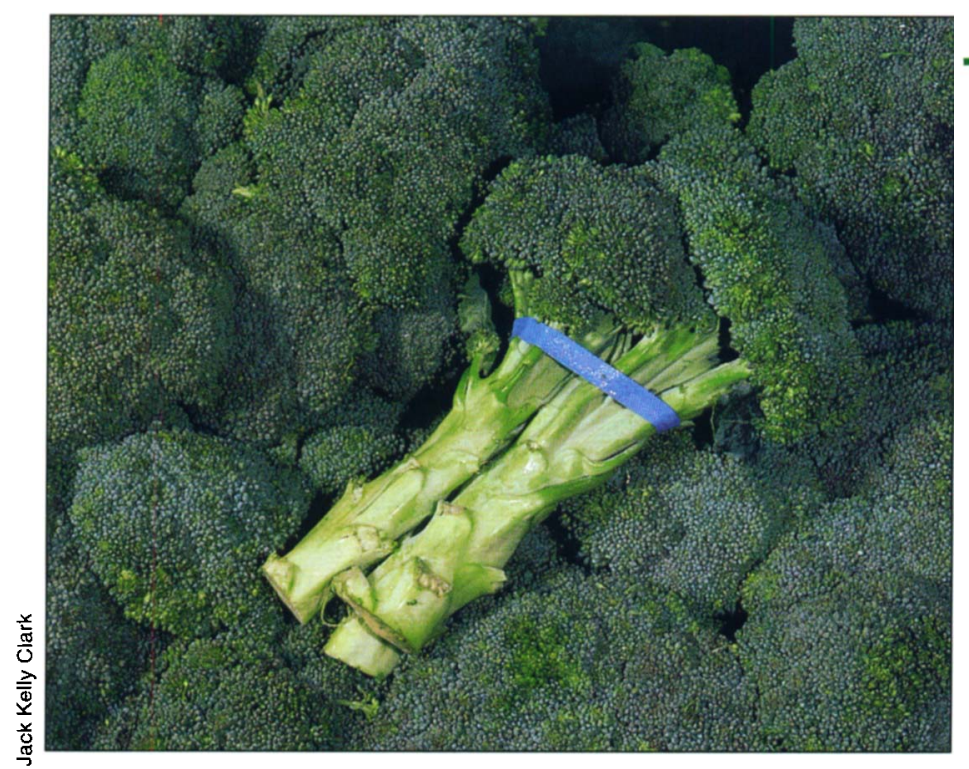

Growers of minor specialty crops, like broccoli, may find that transgenic research that could benefit them is never developed and commercialized because the potential market is too small to attract the attention of the private sector.

ancestors of commercial varieties, may find themselves in a similar situation to the germplasm developer in this case. In the absence of effective recognition of "farmers' rights," they have no bargaining power that could force compensation for the use of their landraces or derived varieties.

If the original variety had received a PVPC after 1994, the situation might be different. The unanswered question of law is whether the new herbicidetolerant variety infringes on the original PVPC, which was held by the public breeder. The issue is whether or not the herbicide-tolerant variety is, in the language of the Act, "essentially derived" from the original variety. If it is, the developer of the transgenic variety would require permission from the original developer to improve the cultivar with the herbicide tolerance gene. Unfortunately the Act does not offer a definition of "essentially derived" that could settle the question. To my knowledge the extent of this legal protection has not been tested in court. Obviously its resolution has powerful implications for owners of PVPC-protected cultivars.

If the original variety were protected by a utility patent, creation of the new cultivar would infringe that patent. That is, a license would be needed from the holders of the patent on the original cultivar in order to market the new variety. If the new cultivar were also patented, the developers of the original variety would similarly need a license to produce or use the genetically engineered version. Who pays and how much they pay for freedom to commercialize the transgenic seed depends upon the relative bargaining position, skills and experience of the parties, areas in which the larger private corporations, at present, tend to have a distinct advantage in most cases.

In reality, this example is not hypothetical. The public rice breeders who developed the elite germplasm for California did not protect it either with a utility patent or a PVPC. All the intellectual property rights are held by the breeder of the herbicide-tolerant germplasm. Rice growers today may have to pay a premium for the herbicide tolerant variety. If public breeding programs are to continue to create new varieties in the manner they have done in the past, they will need to develop strategies to deal with these new realities.

\section{Specialty crops}

Although California's minor acreage crops have not been the prime target of genetic engineering efforts by large agricultural biotechnology companies, these crops could benefit from their application. Part of the reluctance to practice the new technologies on such crops relates to the question of cost. Creation of the engineered varieties involves substantial up-front investments to develop and protect enabling technologies, to identify useful genes, to engage in product advancement, and to negotiate the complicated and challenging regulatory and consumer acceptance issues associated with transgenic crops. Investments in engineering California's minor acreage crops may be hampered by the inability of innovators to capture sufficient revenue to justify their creation; the market may be too small given the costs involved. The traditional solution to this dilemma has been for the public sector to create these new varieties, which makes sense if the overall social benefits exceed the costs.

A serious impediment to public production of genetically engineered crops arises when the key technologies and/or materials (e.g., genes, regulatory elements that control the gene, means of transformation) needed for their development are not obtainable from patent holders on reasonable terms. This situation occurred during the early product development of a new tomato variety. UC researchers, using some state and commodity funds, began the process of creating a tomato variety genetically engineered to express the university's endoglucanase gene to retard softening and improve shelf-life characteristics. The improved variety was being developed from another variety that had been created with public support. The new product included key genetic elements, including a promoter, covered by patent rights held by a private corporation. The latter refused to allow the use of its embodied technology for commercialization. As a result, the research and development effort came to naught, shaking the confidence of the commodity group in the capacity of the university to successfully breed new transgenic cultivars.

\section{What's the problem?}

Economists tend to believe that when there are gains to be made from a trade, the trade will occur. Why, then, did the parties fail to find a mutually satisfactory solution in the above example? Economists would conclude that the "transaction costs" must have been too high (Wright 1998). Perhaps the public sector negotiations had unrealistic expectations regarding private sector largesse. Maybe the owner of the key technology saw no way to protect itself from liability or from damage to its reputation, in the event that the developed products were mismanaged or did not 
perform. Or it could be that the expected financial gains, given the size of the market, were less than the cost in time and money to the corporation of making and enforcing an agreement. Or perhaps the patent holder saw no reason to help out a potential competitor in the tomato market, who might be willing to sell at a lower price.

\section{What are the implications?}

In germplasm development, the days when the public sector could "do it all" are long gone. In major crops like corn and cotton, the private developers of germplasm have gained handsomely from sharing it with biotechnology companies via mergers or takeovers. But the public sector (and commodity groups) cannot expect a similar bonanza when germplasm has been developed over the years in the public sector without patent or trade secret protection, a policy historically consistent with maximizing social benefits. It is now unrealistic to expect private biotech firms who use it to produce new transgenic varieties to share any of the profits. Thus, though the tools of germplasm development have become more expensive via privatization, in general the prospects of profitable commercialization of new cultivars by public sector breeders or commodity groups have not similarly increased. Public breeders could try to improve their bargaining position by developing new lines with intellectual property protection, but it might take years before they can establish sufficient improvement over what others can achieve starting with today's freely available germplasm.

However, for many years now, the trend has been in the other direction. In many larger crops, the days of nonprofit germplasm development seem to be over in the United States. Universities and experiment stations will continue and even expand their role in producing innovative traits that will be licensed to private seed producers for use in their germplasm. Though the private sector is currently providing a wide array of exciting new technologies, farmers should support measures which reduce the tendency to monopolization of seed production. For example, proposals that increase the cost of regulatory requirements, such as field tests, should be carefully scrutinized to ensure that they are justified by their benefits to consumers. Increased regulatory burdens tend to favor large incumbent firms against fringe players and potential entrants.

Continued public production of germplasm with commodity-group financing may be necessary for crops not sufficiently attractive to the large firms that control much of the necessary biotechnology. Attention should be given to appropriate intellectual property protection on new cultivars, and to developing appropriate contractual means of public-private cooperation, and reducing the substantial transactions costs of such deals. Furthermore, researchers must now pay close attention to the nature of their rights to research inputs in breeding new cultivars; a research license, for example, does not permit commercialization and leaves successful developers subject to "hold-up" problems by the rights' owner. As more experience is gained by all parties in handling these challenges, it should be possible to structure the roles of the public and private sector so that the very great potential of new biotechnology-based agronomic and output traits can be realized across the wide range of crops grown in California.

B.D. Wright is Professor, Department of Agricultural and Resource Economics,

UC Berkeley.

The author thanks Marlon Brandon, Director of the Rice Experiment Station, Biggs, CA and Alan Bennett, Associate Dean of Plant Sciences at UC Davis, for their critical comments on the manuscript and the sharing of their stories.

\section{References}

Barton JH, Siebeck WE. 1994. Material Transfer Agreements in Genetic Resource Exchange: The Case of the International Agricultural Research Centers. Issues in Genetic

Resources, No. 1, International Plant Genetic

Rescues Institute, Rome, Italy.

Enriquez J. 1998. Genomics and the world's economy. Science 281(5379):925-6.

Fowler C. 1994. Unnatural Selection: Technology, Politics, and Plant Evolution. In-

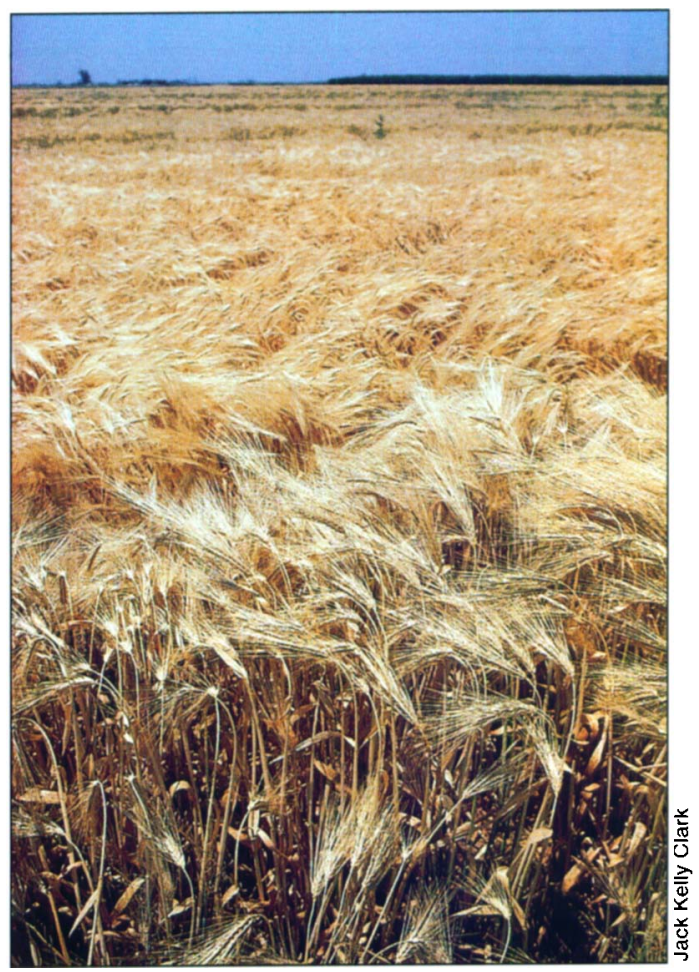

In the absence of enforceable "farmers' rights" or other property rights, farmers who over the centuries have helped develop landrace ancestors of commercial varieties may find that they have no bargaining power that could force compensation for the use of their landraces or derived varieties in breeding transgenic varieties.

ternational Studies in Global Change, Gordon and Breach Science Publishers, Yverdon, Switzerland.

Juma C. 1989. The Gene Hunters: Bio technology and the Scramble for Seeds. African Center for Technology Studies Research Series, No.1. Princeton University Press, Princeton, NJ.

Koo B. 1998. The Economics of Plant Genetic Resources: The Effects of Alternative Intellectual Property Protection Systems and Advances in Biotechnology. Unpublished Ph.D. dissertation, Department of Agricultural and Resource Economics, University of California, Berkeley.

Lappé M, Bailey B. 1998. Against the

Grain. Monroe, ME: Common Courage Press. $163 \mathrm{p}$.

Miller JP. 1998. Pioneer Hi-Bred Int'|

Faces Long Legal Fight. Dow Jones Newswires. Oct. 29, 1998.

Pollan M. 1998. Playing God in the Garden. NY Times Mag. Oct. 25, 1998.

Powledge F. 1995. "Who owns rice and beans? Patents on plant germplasm." BioScience, 45(7): 440-5.

Robinson D. Personal communication. Nov. 20, 1998.

Wright B. 1998. "Operation of Public Agricultural Research and Extension in a World of Proprietary Science and Technology." Paper presented at conference Knowledge Generation and Transfer: Implications for Agriculture in the 21st Century. July 1998, Berkeley, CA. 